\title{
Characterization of atmospheric nitrous oxide emissions from global agricultural soils
}

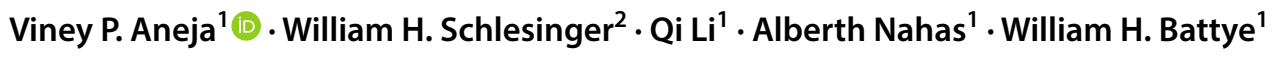

Received: 30 August 2019 / Accepted: 13 November 2019 / Published online: 23 November 2019

(c) Springer Nature Switzerland AG 2019

\begin{abstract}
Nitrous oxide $\left(\mathrm{N}_{2} \mathrm{O}\right)$ is a potent greenhouse gas with an atmospheric lifetime of $\sim 114$ years. Agriculture activities are the main sources for $\mathrm{N}_{2} \mathrm{O}$ emission into the atmosphere by human activities. Global $\mathrm{N}_{2} \mathrm{O}$ emissions into the atmosphere are projected to increase in the coming years as demand for food, fibre and energy increases owing to increasing global population. Here, a statistical model $\left(\mathrm{N}_{2} \mathrm{O} \_\mathrm{STAT}\right)$ is developed for characterizing atmospheric $\mathrm{N}_{2} \mathrm{O}$ emissions from agricultural sources. We obtained $\mathrm{N}_{2} \mathrm{O}$ emissions and physicochemical variables (i.e. air temperature, soil temperature, soil moisture, soil $\mathrm{pH}$, and $\mathrm{N}$ input to the soil) from published journal articles since 2000. A statistical model was developed by expressing a multiple linear regression equation between $\mathrm{N}_{2} \mathrm{O}$ emission and the physicochemical variables. The model was evaluated for $2012 \mathrm{~N}_{2} \mathrm{O}$ emissions. Results of the model are compared with other global and regional $\mathrm{N}_{2} \mathrm{O}$ models (e.g. EDGAR, EPA/USGS, and FAOSTAT). In comparison with other data sets, the model generates a lower global $\mathrm{N}_{2} \mathrm{O}$ estimate by 9-20\% ( $\mathrm{N}_{2} \mathrm{O} \_$STAT: $3.75 \mathrm{Tg} \mathrm{N} \mathrm{yr}^{-1}$; EDGAR: 4.49 $\mathrm{Tg} \mathrm{N} \mathrm{yr}^{-1}$; FAO: $4.07 \mathrm{Tg} \mathrm{N} \mathrm{yr}^{-1}$ ), but is $\sim 25 \%$ higher when compared to Bouwman et al. (Glob Biogeochem Cycles 16:1-9. https://doi.org/10.1029/2001 gb001812, 2002) $\left(2.80 \mathrm{Tg} \mathrm{N} \mathrm{yr}^{-1}\right)$. We also performed a region-based analysis (USA, India, and China) using the $\mathrm{N}_{2} \mathrm{O}$ _STAT model. For the USA, our model produces an estimate that ranges from -13 to $+32 \%$ in comparison with other published data sets. Meanwhile, the $\mathrm{N}_{2} \mathrm{O} \_$STAT model estimate for India shows $\mathrm{N}_{2} \mathrm{O}$ emissions between -56 and $+14 \%$ when compared to other data sets. A much lower estimate is seen for China, where the model estimates $\mathrm{N}_{2} \mathrm{O}$ emissions $38-177 \%$ lower than other data sets. The $\mathrm{N}_{2} \mathrm{O}_{-} \mathrm{STAT}$ model provides an opportunity to predict future $\mathrm{N}_{2} \mathrm{O}$ emissions in a changing world.
\end{abstract}

Keywords Nitrous oxide $\cdot$ Emissions $\cdot$ Agricultural soil $\cdot$ Statistical model

\section{Introduction}

The largest human influence on climate since the end of the twentieth century is the emission of greenhouse gases to the atmosphere. In addition to carbon dioxide $\left(\mathrm{CO}_{2}\right)$, nitrous oxide $\left(\mathrm{N}_{2} \mathrm{O}\right)$ is one of the most important greenhouse gases that has a global warming potential (GWP) of $\sim 300$ for a 100-year timescale [1]. $\mathrm{N}_{2} \mathrm{O}$ also contributes to the destruction of ozone in the stratosphere [2]. The lifetime of $\mathrm{N}_{2} \mathrm{O}$ in the atmosphere is $\sim 114$ years, indicating its long-term influence on a planetary scale [3].

Since 1978 , globally averaged $\mathrm{N}_{2} \mathrm{O}$ concentrations in the atmosphere have been measured at Mauna Loa, Hawaii. Prior to $1978, \mathrm{~N}_{2} \mathrm{O}$ levels were extracted from ice cores from Antarctica. $\mathrm{N}_{2} \mathrm{O}$ concentrations in the atmosphere were relatively stable until the start of the Industrial Revolution [4]. Since that time, $\mathrm{N}_{2} \mathrm{O}$ concentration has increased by $18 \%$, from $\sim 270 \mathrm{ppb}$ to the current value of $\sim 331 \mathrm{ppb}$

Electronic supplementary material The online version of this article (https://doi.org/10.1007/s42452-019-1688-5) contains supplementary material, which is available to authorized users.

Viney P. Aneja, vpaneja@ncsu.edu| 'Department of Marine, Earth, and Atmospheric Sciences, North Carolina State University, Raleigh, NC 27695-8208, USA. ${ }^{2}$ Cary Institute of Ecosystem Studies, Millbrook, NY 12545, USA. 
(Fig. 1). This increase is primarily due to intensive human activities, particularly related to agriculture.

Ciais et al. [5] have estimated the yearly emission of $\mathrm{N}_{2} \mathrm{O}$ to be 17.9 $\mathrm{Tg} \mathrm{N} \mathrm{yr}^{-1}$ for the period 2006-2011. $\mathrm{N}_{2} \mathrm{O}$ emissions from natural sources are $11.0 \mathrm{Tg} \mathrm{N} \mathrm{yr}^{-1}$, which includes sources from land and oceans. Agricultural activities are the primary anthropogenic source of $\mathrm{N}_{2} \mathrm{O}$, contributing to $5.6 \mathrm{Tg} \mathrm{N} \mathrm{yr}^{-1}$ [6]. With increasing food, fibre and energy production, along with climate change and agricultural intensification, $\mathrm{N}_{2} \mathrm{O}$ emissions from soils have increased since 1990, from 3.5 $\mathrm{Tg} \mathrm{N} \mathrm{yr}^{-1}$ to $4.1 \mathrm{Tg} \mathrm{N} \mathrm{yr}^{-1}$ [7].

During the period 1961-2010, global $\mathrm{N}_{2} \mathrm{O}$ emissions from manure usage have grown from 1.17 to $2.03 \mathrm{Tg} \mathrm{N} \mathrm{yr}^{-1}$ at an average rate of $1.10 \% \mathrm{yr}^{-1}$ [8]. Meanwhile during the same period, $\mathrm{N}_{2} \mathrm{O}$ emissions from synthetic fertilizers have increased from 0.14 to $1.40 \mathrm{Tg} \mathrm{N} \mathrm{yr}^{-1}$ at an average rate of $3.90 \% \mathrm{yr}^{-1}$ globally [9]. This indicates that synthetic fertilizers will have a greater contribution to $\mathrm{N}_{2} \mathrm{O}$ emission than manure within less than 10 years [8]. Besides agriculture, other sources such as fossil fuel combustion, industrial processes, and biomass burning also contribute to the total $\mathrm{N}_{2} \mathrm{O}$ emissions, but these are all relatively small sources.

Intensive fertilizer use has increased the emissions of reactive nitrogen compounds, including $\mathrm{N}_{2} \mathrm{O}$ from soils through nitrification and denitrification processes (Supplementary Figure 1S). Nitrification is the aerobic microbial oxidation of ammonium or ammonia to nitrite followed by oxidation of nitrite to nitrate. It is an important process in the nitrogen cycle in which $\mathrm{N}_{2} \mathrm{O}$ is generated as a by-product that leaks from microbial cells into soil and eventually into the atmosphere [6]. Denitrification is a microbially facilitated process that leads to significant $\mathrm{N}$ losses from agricultural systems. Through denitrification, nitrate and nitrite are reduced, and a portion converted into $\mathrm{N}_{2} \mathrm{O}$ [10].

The ratios of $\mathrm{N}_{2} \mathrm{O} / \mathrm{NO}_{3}{ }^{-}$(nitrification) to $\mathrm{N}_{2} \mathrm{O} / \mathrm{N}_{2}$ (denitrification) products are important parameters determining the change of global budget, and they are affected by various physical, chemical and biological factors and their interacting effects [11]. To develop a predictive model for $\mathrm{N}_{2} \mathrm{O}$ emission under different agroecosystems, climate variables, soil characteristics, and cropping practices must be considered. Granli and Bockman [11] provided a review of the factors that control $\mathrm{N}_{2} \mathrm{O}$ emissions from soil, including moisture and aeration, temperature, soluble and decomposable carbon, soil and fertilizer

Table 1 Variables that affect product ratios during nitrification and denitrification in agricultural soils [11,34]

\begin{tabular}{|c|c|c|}
\hline Process & Variable & Effect \\
\hline & & Will increase $\mathrm{N}_{2} \mathrm{O} / \mathrm{NO}_{3}^{-}$ratio \\
\hline \multirow[t]{6}{*}{ Nitrification } & {$\left[\mathrm{O}_{2}\right]$} & Decreasing $\mathrm{O}_{2}$ concentration \\
\hline & {$\left[\mathrm{H}_{2} \mathrm{O}\right]$} & $\begin{array}{l}\text { Increasing } \mathrm{H}_{2} \mathrm{O} \text { above field } \\
\text { capacity }\end{array}$ \\
\hline & {$\left[\mathrm{NH}_{4}^{+}\right]$} & Low $\mathrm{NH}_{4}{ }^{+}$concentrations \\
\hline & $\mathrm{pH}$ & Increasing or decreasing $\mathrm{pH}$ \\
\hline & Temperature & Increasing temperature \\
\hline & & Will increase $\mathrm{N}_{2} \mathrm{O} / \mathrm{N}_{2}$ ratio \\
\hline \multirow[t]{7}{*}{ Denitrification } & {$\left[\mathrm{NO}_{3}^{-}\right]$or $\left[\mathrm{NO}_{2}^{-}\right]$} & Increasing oxidant \\
\hline & {$\left[\mathrm{O}_{2}\right]$} & Increasing $\mathrm{O}_{2}$ \\
\hline & Carbon & Decreasing $C$ availability \\
\hline & $\mathrm{pH}$ & Decreasing $\mathrm{pH}$ \\
\hline & Temperature & Decreasing temperature \\
\hline & Enzyme status & Low $\mathrm{N}_{2} \mathrm{O}$ reductase activity \\
\hline & {$\left[\mathrm{H}_{2} \mathrm{O}\right]$} & $\begin{array}{l}\text { Decreasing between } 60 \text { and } 90 \% \\
\text { WFPS }\end{array}$ \\
\hline
\end{tabular}

Fig. 1 Atmospheric $\mathrm{N}_{2} \mathrm{O}$ concentration trend from the combined Global Monitoring Division data set for the period 1977-2018 [33]

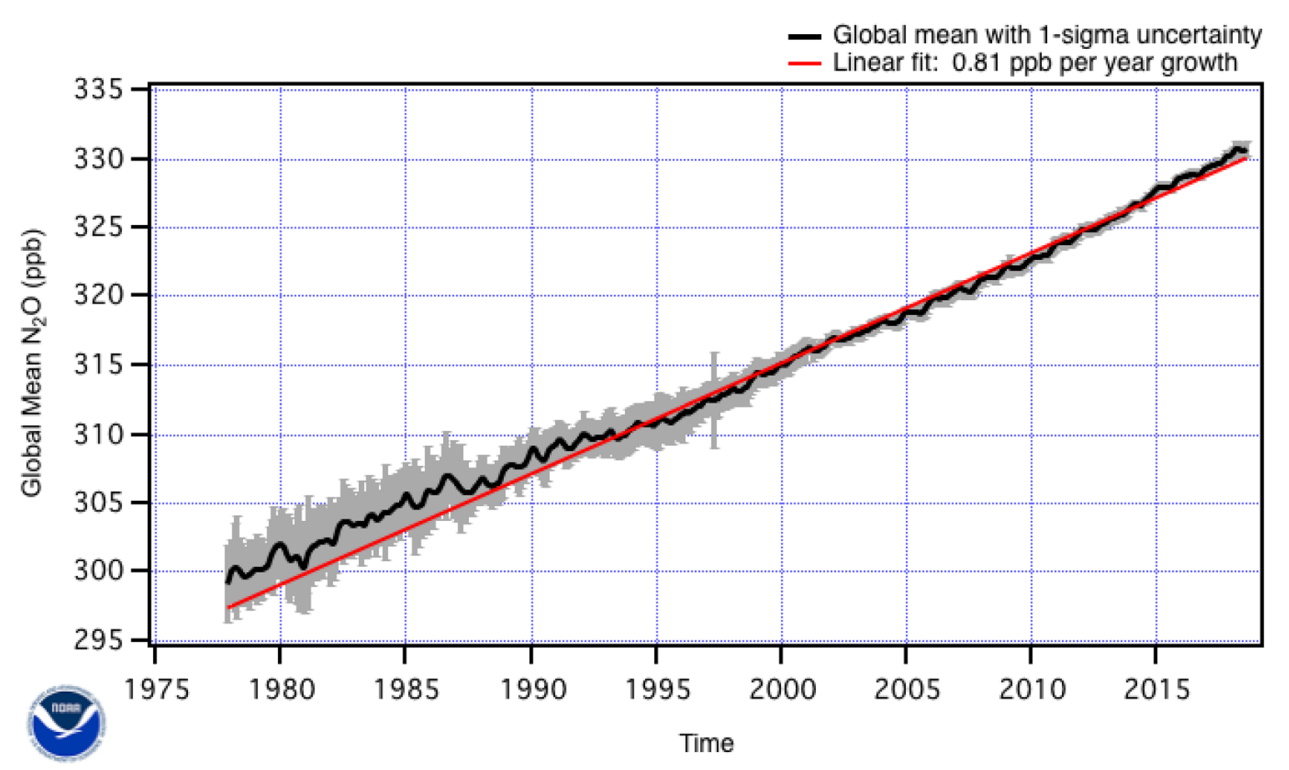


nitrogen, soil $\mathrm{pH}$ and salinity. Table 1 summarizes the variables that affect product ratios during nitrification and denitrification in agricultural soils. In nitrification, $\mathrm{N}_{2} \mathrm{O}$ emission will increase with decreasing $\mathrm{O}_{2}$ concentration, increasing water above field capacity, low $\mathrm{NH}_{4}^{+}$ concentrations, deviations of $\mathrm{pH}$ from near neutrality, and increasing temperature. The production of $\mathrm{N}_{2} \mathrm{O}$ by denitrification is enhanced in conditions characterized by high nitrate, high $\mathrm{C}$ availability, low $\mathrm{pH}$, high temperature, low $\mathrm{N}_{2} \mathrm{O}$ reductase activity, and $60-90 \%$ water-filled pore space (WFPS) [12-14].

Uncertainties of estimates of sources and sinks still exist in global $\mathrm{N}_{2} \mathrm{O}$ budget, especially from agricultural soils [15]. Inadequate understanding of the mechanisms controlling $\mathrm{N}_{2} \mathrm{O}$ emission from agricultural soils may be responsible for limited attention to agriculture as a major contributor of the increasing atmospheric $\mathrm{N}_{2} \mathrm{O}$. With increasing food and energy production, along with climate change and agricultural intensification, $\mathrm{N}_{2} \mathrm{O}$ emissions from soils and groundwater are likely to increase, indicating the need for an updated global budget for $\mathrm{N}_{2} \mathrm{O}$ that accounts for these recent changes.

The goal of this project is to develop a statistical model to predict $\mathrm{N}_{2} \mathrm{O}$ emissions from agricultural soils containing synthetic and organic fertilizers using physicochemical properties of the system from different regions. We also analyse the spatial distribution of $\mathrm{N}_{2} \mathrm{O}$ emissions from agricultural soils and compare the results with other modelled emission inventories (i.e. EDGAR v.4.3.2, EPA, and FAOSTAT).

\section{Methodology}

Based on literature review, we found four variables of importance in controlling $\mathrm{N}_{2} \mathrm{O}$ emissions from soil: (1) soil moisture, (2) soil and air temperature, (3) synthetic and organic fertilizer usage, and (4) soil pH [16]. The highest $\mathrm{N}_{2} \mathrm{O}$ emissions are usually due to high temperature and ample precipitation because increasing soil temperature stimulates microbial activities related to nitrification and denitrification. We performed a series of statistical analyses utilizing the RStudio statistical software (https://github.com/rstudio/rstudio) to examine the distribution of data and to fit an appropriate regression model with $\mathrm{N}_{2} \mathrm{O}$ as the response (dependent) variable and other variables as independent predictors. We then used Integrated Land and Water Information System (ILWIS) v.3.31 Academic (https://www.itc.nl/ilwis /download/ilwis33/), a GIS tool to prepare the global data sets and apply the statistical model to predict $\mathrm{N}_{2} \mathrm{O}$ emissions.

\subsection{Data collection}

Data collection includes two parts: (1) data sets for developing the statistical model (Table 2) and (2) global data sets for extrapolating the results to larger areas (Table 3). For the statistical model, we conducted a literature review regarding agricultural soil $\mathrm{N}_{2} \mathrm{O}$ emission (published after 2000). Data were derived from two sources: (1) field data for developing the statistical model and (2) global data for extrapolating the results to larger areas. The complete data set is compiled in Supplementary Table 1S.

\subsection{Model development}

Based on the statistical analysis, we found that the data distribution, shown as the histogram of $\mathrm{N}_{2} \mathrm{O}$ emissions (Fig. 2a), was skewed to the right. To normalize the data, we transformed them to logarithmic values (Fig. 2b), which were normally distributed. Then, we used a multiple linear regression model to fit the response variable (the log of $\mathrm{N}_{2} \mathrm{O}$ emissions), using the physicochemical variables as predictors. The statistically derived model (hereinafter $\mathrm{N}_{2} \mathrm{O}_{-} \mathrm{STAT}$ ) to predict $\mathrm{N}_{2} \mathrm{O}$ emissions from agricultural soils is mathematically expressed as the following:

$$
\begin{aligned}
\mathrm{N}_{2} \text { O emission }= & \left(\operatorname { e x p } \left[A+B \times T_{\text {soil }}+C \times \mathrm{SM}+D \times \mathrm{pH}_{\text {soil }}\right.\right. \\
& +E \times \mathrm{N} \text { input }+F \times \text { Fertilizer type }]) \times \frac{28}{44}
\end{aligned}
$$

where $T_{\text {soil }}$ refers to soil temperature $\left({ }^{\circ} \mathrm{C}\right), \mathrm{SM}$ soil moisture (\%), and the coefficients $A, B, C, D, E$, and $F$ are statistically derived parameters (Table 4). $\mathrm{N}$ input is differentiated by synthetic or organic fertilizer and is expressed as $\mathrm{kg} \mathrm{N}$ $\mathrm{ha}^{-1} \mathrm{yr}^{-1}$. The units for predicted $\mathrm{N}_{2} \mathrm{O}$ emission are $\mathrm{kg} \mathrm{N}$ $\mathrm{ha}^{-1} \mathrm{yr}^{-1}$. Initially, air temperature was included as a variable in the model, but it was later omitted from the equation because it had an insignificant correlation with $\mathrm{N}_{2} \mathrm{O}$ emission.

Table 4 summarizes the coefficients and $p$ values of each variable. The residual standard error is 0.928 , and $R$-squared is 0.2 . The $\mathrm{F}$ test shows that this multivariate linear regression model is statistically significant at $90 \%$ confidence level. Based on the $p$ value, the soil moisture, soil $\mathrm{pH}$, and fertilizer type are statistically significant. Notably, the magnitude of nitrogen input does not have a significant influence on the $\mathrm{N}_{2} \mathrm{O}$ emission rate. This may seem counterintuitive, but $\mathrm{N}_{2} \mathrm{O}$ emissions are produced by nitrification and denitrification, and nitrogen concentrations may be the limiting factor for these reactions only when the levels of soil nitrogen are low. Other factors are likely to be limiting when soil nitrogen concentrations are at agronomic levels [6]. Yu and Zhuang [16] corroborate these findings using their trait-based biogeochemistry 
Table 2 Data for statistical model development

\begin{tabular}{ll}
\hline Parameter & Unit \\
\hline $\mathrm{N}_{2} \mathrm{O}$ emissions & $\mathrm{kg} \mathrm{N} \mathrm{ha}^{-1}$ year $^{-1}$ \\
Air temperature & ${ }^{\circ} \mathrm{C}$ \\
Soil temperature & ${ }^{\circ} \mathrm{C}$ \\
Soil pH & - \\
Soil moisture & $\%$ \\
Fertilizer N content usage & $\mathrm{kg} \mathrm{N} \mathrm{ha}^{-1}$ year $^{-1}$ \\
Manure N content usage & $\mathrm{kg} \mathrm{N} \mathrm{ha}^{-1}$ year $^{-1}$ \\
\hline
\end{tabular}

Table 4 Summary of the statistical model

\begin{tabular}{llrl}
\hline Variable & Parameter & Coefficient & $p$ value \\
\hline A & Intercept & 1.3437 & 0.0295 \\
B & Soil temperature & 0.0291 & 0.0515 \\
C & Soil moisture & 0.0196 & 0.0003 \\
D & Soil pH & -0.3454 & 0.0007 \\
E & Nitrogen input & 0.0003 & 0.5802 \\
F & Fertilizer type & 0.4567 & 0.0073 \\
\hline
\end{tabular}

Table 3 Global data set used for prediction

\begin{tabular}{ll}
\hline Parameter & Data sets \\
\hline Soil temperature; soil pH & $\begin{array}{l}\text { Harmonized World Soil Database v 1.2 } \\
\text { http://www.fao.org/soils-portal/soil-survey/soil-maps-and-databases/harmonized-world-soil- } \\
\text { database-v12/en/ } \\
\text { The Global Soil Dataset for Earth System Modeling } \\
\text { Soil moisture }\end{array}$ \\
$\begin{array}{l}\text { Air temperature } \\
\text { ERA-Interim Global Atmospheric Reanalysis }\end{array}$ \\
$\begin{array}{l}\text { https://www.ecmwf.int/en/forecasts/datasets/archive-datasets/reanalysis-datasets/era-interim } \\
\text { Cropland cover, fertilizer usage, manure } \\
\text { usage }\end{array}$ \\
$\begin{array}{l}\text { EarthStat's Cropland and Pasture Area (with modification) } \\
\text { http://www.earthstat.org/ }\end{array}$ \\
\hline
\end{tabular}

model to estimate global $\mathrm{N}_{2} \mathrm{O}$ emissions that were more sensitive to temperature and precipitation and less sensitive to soil organic carbon and nitrogen contents.

\subsection{Model diagnostics}

After running the regression analysis, we verified that $\mathrm{N}_{2} \mathrm{O}_{\text {SSTAT }}$ works well for fitting the data and complies with the assumptions of linear regression models. A two-step model diagnostic was performed by analysing the variance and distribution of the residuals (Supplementary Figure $2 \mathrm{~S}$ ). The equal distribution with no distinct patterns of residuals around the horizontal provides a good indication

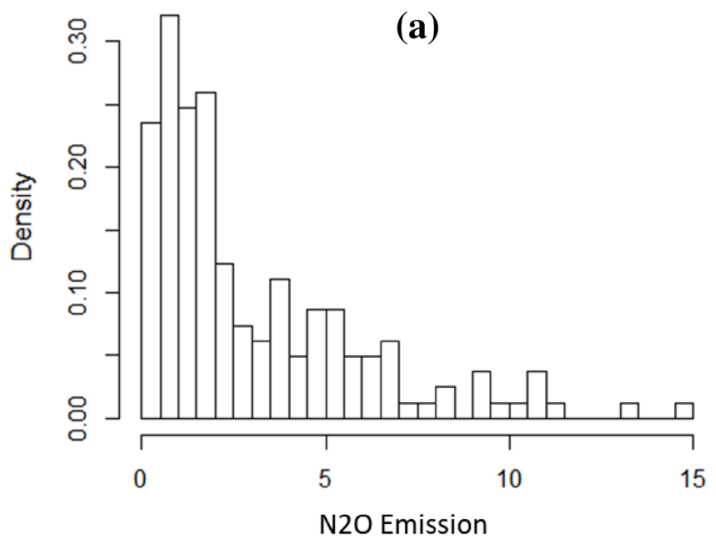

of the likelihood of a linear relationship. Additionally, the residuals are well fitted on the straight line, indicating that the data are indeed normally distributed. The outliers indicated by residuals that are far from the line were excluded in further analysis.

We tested different model forms, i.e. linear form (classical emission factor approach) and exponential form (this study). The exponential form had $r^{2}=0.2$, and residual standard error $=0.93$, which are better than in the linear model $\left(r^{2}=0.14\right.$ and residual standard error $\left.=1.02\right)$, suggesting that the exponential model is preferred in modelling the $\mathrm{N}_{2} \mathrm{O}$ emission.

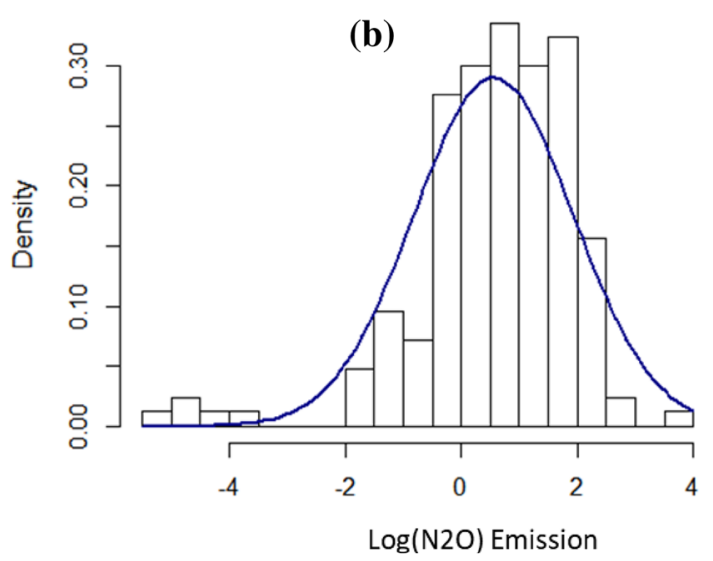

Fig. 2 a Histogram of $\mathrm{N}_{2} \mathrm{O}$ emission and $\mathbf{b} \log$ of $\mathrm{N}_{2} \mathrm{O}$ emission 


\subsection{Other $\mathrm{N}_{2} \mathrm{O}$ emission inventories}

\subsubsection{EDGAR}

The Emission Database for Global Atmospheric Research compiles anthropogenic global $\mathrm{N}_{2} \mathrm{O}$ emissions and trends from 1970 to 2012 based on international statistics and emission factors [17]. $\mathrm{N}_{2} \mathrm{O}$ emissions from fertilizer are based on the estimation from the International Fertilizer Industry Association (IFA) and the Food and Agriculture Organization Statistics Division (FAOSTAT). The $\mathrm{N}_{2} \mathrm{O}$ emission factor for direct soil emissions from the use of synthetic fertilizer and from manure and from crop residues is based on IPCC Guideline [7]. For the comparison purposes, we use the 2012 global $\mathrm{N}_{2} \mathrm{O}$ data set for agricultural soils (subsector 4C+4D).

\subsubsection{EPA greenhouse gas inventory report and USGS county-level data sets}

We calculated $\mathrm{N}_{2} \mathrm{O}$ emission from agriculture soils over the continental USA based on subsectors described in the EPA report [18]. The subsector emissions are taken from the county-level information compiled by USGS from the 2012 census of agriculture $[19,20]$. The county-level information consists of fertilizer usage, manure applications, and crop residue. Then we calculated the emissions which are interpolated to generate a spatial distribution of the emission for the USA.

\subsubsection{FAOSTAT (http://www.fao.org/faostat/en/)}

Food and Agriculture Organization of the United Nations develops methods and standards for food and agriculture statistics, provides technical assistance services, and disseminates data for global monitoring. It provides the $\mathrm{N}_{2} \mathrm{O}$ global emissions from synthetic fertilizers, manure applied to soils, manure left on pasture, and crop residues in 2012.

\section{Results}

\subsection{Global}

After calculating the coefficients for all variables, we applied the $\mathrm{N}_{2} \mathrm{O}$ _STAT model for each grid cell and generated a global map for $\mathrm{N}_{2} \mathrm{O}$ emissions. Figure 3a gives the spatial distribution of global $\mathrm{N}_{2} \mathrm{O}$ emission from agricultural soils calculated using $\mathrm{N}_{2} \mathrm{O}$ _STAT in $\mathrm{kg} \mathrm{Nyr}^{-1}$ grid cell ${ }^{-1}$. The resolution of this map is 5 arc-minute by 5 arc-minute, which is equivalent to 8464 ha. The average $\mathrm{N}_{2} \mathrm{O}$ emission from agricultural soils is $\sim 9000 \mathrm{~kg} \mathrm{~N}$ $\mathrm{yr}^{-1}$ grid cell ${ }^{-1}$, which is comparable to average values of
$1 \mathrm{~kg} \mathrm{ha}^{-1}$ for agricultural soils, reported by Kim et al. [21] and Shcherbak et al. [22].

Figure $3 \mathrm{~b}$ shows spatial distribution of global $\mathrm{N}_{2} \mathrm{O}$ emission from agricultural soil based on EDGAR. Total annual global $\mathrm{N}_{2} \mathrm{O}$ emissions from $\mathrm{N}_{2} \mathrm{O}_{\text {STATT }}$ and EDGAR are 3.75 $\mathrm{Tg} \mathrm{N} \mathrm{yr}^{-1}$ and $4.49 \mathrm{Tg} \mathrm{N} \mathrm{yr}^{-1}$, respectively. It is encouraging to see that, in general, the model captures the global spatial pattern in $\mathrm{N}_{2} \mathrm{O}$ emissions well. Figure $3 \mathrm{c}$ shows the absolute difference between $\mathrm{N}_{2} \mathrm{O}$ _STAT and EDGAR. In comparison with EDGAR, $\mathrm{N}_{2} \mathrm{O}_{-}$STAT gives lower $\mathrm{N}_{2} \mathrm{O}$ emission values in North America, South America, India, and China, while higher values in Eastern Europe and mid-Africa.

\subsection{Continental USA, India, and China}

Figure 4 provides the comparison between the results from $\mathrm{N}_{2} \mathrm{O}_{-} \mathrm{STAT}$, EDGAR, and EPA/USGS over the continental USA (hereafter listed as USA). Total $\mathrm{N}_{2} \mathrm{O}$ emissions from agricultural soils in the USA calculated from $\mathrm{N}_{2} \mathrm{O}$ _STAT, EDGAR, and EPA/USGS are $0.35 \mathrm{Tg} \mathrm{N} \mathrm{yr}^{-1}, 0.43 \mathrm{Tg} \mathrm{N} \mathrm{yr}^{-1}$, and $0.46 \mathrm{Tg} \mathrm{N} \mathrm{yr}^{-1}$, respectively. $\mathrm{N}_{2} \mathrm{O}$ _STAT performs well in capturing the spatial pattern and the total annual emission. Figure 5 gives the absolute difference of $\mathrm{N}_{2} \mathrm{O}$ emissions between $\mathrm{N}_{2} \mathrm{O}$ _STAT model and EDGAR and between $\mathrm{N}_{2} \mathrm{O} \_$STAT and EPA/USGS. Based on Fig. 5a, $\mathrm{N}_{2} \mathrm{O}$ _STAT underestimates $\mathrm{N}_{2} \mathrm{O}$ emission in the Midwest region of the USA and overestimates emissions in the south-eastern region, compared with EDGAR. Figure $5 \mathrm{~b}$ shows that $\mathrm{N}_{2} \mathrm{O}_{-}$ STAT gives lower $\mathrm{N}_{2} \mathrm{O}$ emission values in northern Texas, California, Florida, and states around Lake Michigan, while in other areas the values are comparable to EPA/USGS.

Figure 6 and Table 5 show close agreement with the $\mathrm{N}_{2} \mathrm{O} \_\mathrm{STAT}$ estimate of agricultural soil emissions for India when compared with EDGAR ( -14\%), the finely resolved $\mathrm{N}_{2} \mathrm{O}$ emission estimate by Aneja et al. [23] ( 17\%), and FAOSTAT ( - 7\%). Moreover, Table 5 compares the finely resolved $\mathrm{N}_{2} \mathrm{O}$ emission for India with other published studies. The Aneja et al. [23] results are higher than the results of Garg et al. [24] and Sharma et al. [25], perhaps due to the selection of higher emission factors by Aneja et al. [23]. Overall, we believe that Aneja et al. [23] is more appropriate because these researchers used the activity-level data at district levels and chose the emission factors suitable for Asian context.

Meanwhile for China, our estimate using $\mathrm{N}_{2} \mathrm{O}$ _STAT is 2.3-2.8 times lower than those estimated by EDGAR and $\mathrm{FAO}$. Our $\mathrm{N}_{2} \mathrm{O}$ emission estimate, however, is in good agreement with Gao et al. [26] and Zhou et al. [27] being $2 \%$ higher and $38 \%$ lower, respectively. These two studies employ different methods in estimating $\mathrm{N}_{2} \mathrm{O}$ emission from Chinese agricultural soils. Gao et al. [26] studied $\mathrm{N}_{2} \mathrm{O}$ direct emissions from croplands by using localized 
Fig. 3 Comparison between the results from $\mathbf{a} \mathrm{N}_{2} \mathrm{O} \_\mathrm{STAT}, \mathbf{b}$ EDGAR, and $\mathbf{c}$ absolute difference between the two models (in ton $\mathrm{N}_{2} \mathrm{O} \mathrm{yr}^{-1}$ grid cell ${ }^{-1}$ ). The maps are generated using ILWIS v3.8.5 (https://52nor th.org/software/software-proje cts/ilwis/ilwis-3/)
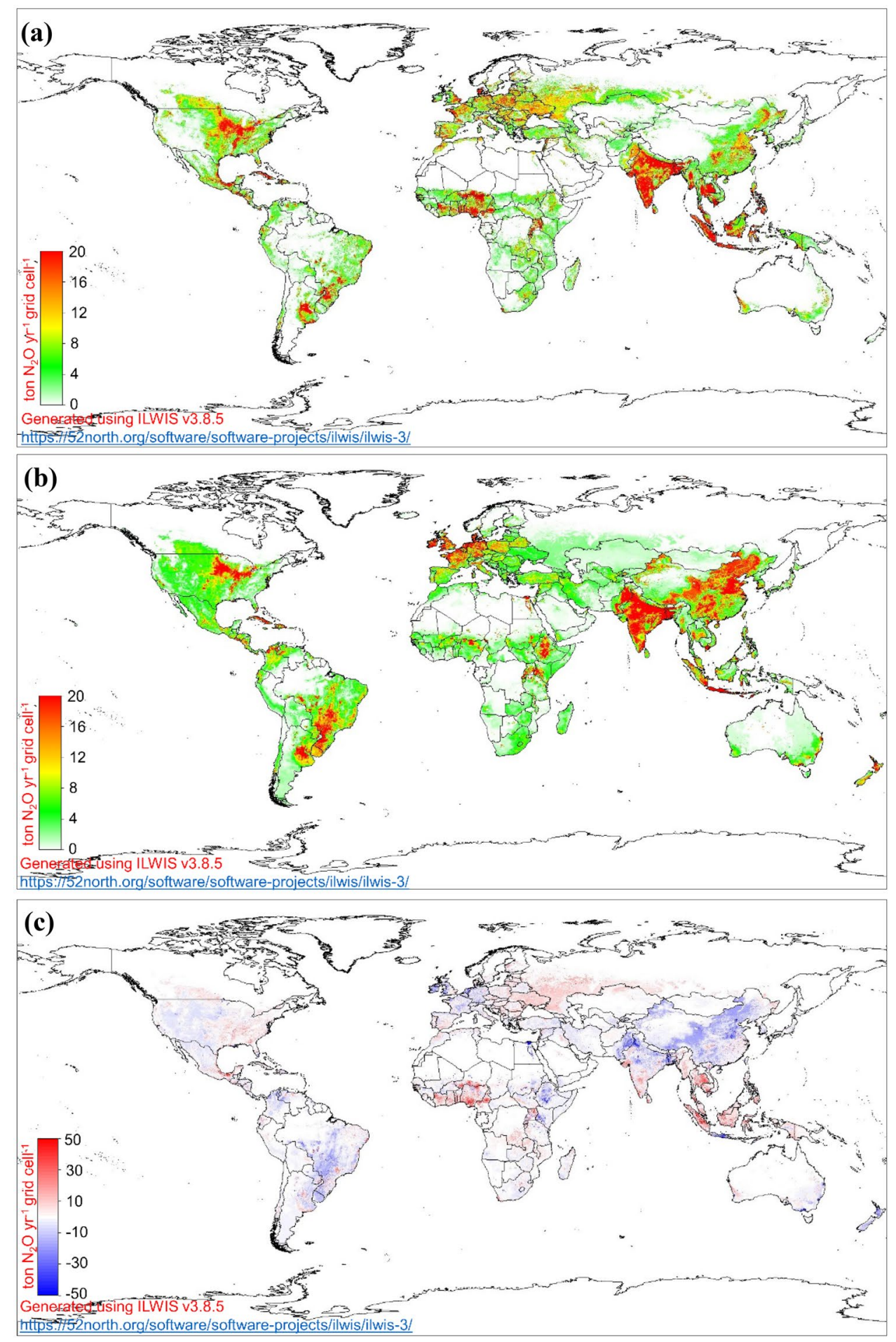

emission factors, while Zhou et al. [27], in addition to using regional emission factors, utilized high-resolution activity data and localized parameters.

\section{Discussion}

We have developed a novel way to approach global nitrous oxide emissions from agricultural soils $\left(\mathrm{N}_{2} \mathrm{O}_{-}\right.$ STAT). We have also used three case studies (USA, India, 
Fig. 4 Comparison between the results from $\mathbf{a} \mathrm{N}_{2} \mathrm{O} \_$STAT, $\mathbf{b}$ EDGAR, and c EPA/USGS (in ton $\mathrm{N}_{2} \mathrm{O} \mathrm{yr}^{-1}$ grid cell $^{-1}$ ). The maps are generated using ILWIS v3.8.5 (https://52north.org/ software/software-projects/ ilwis/ilwis-3/)
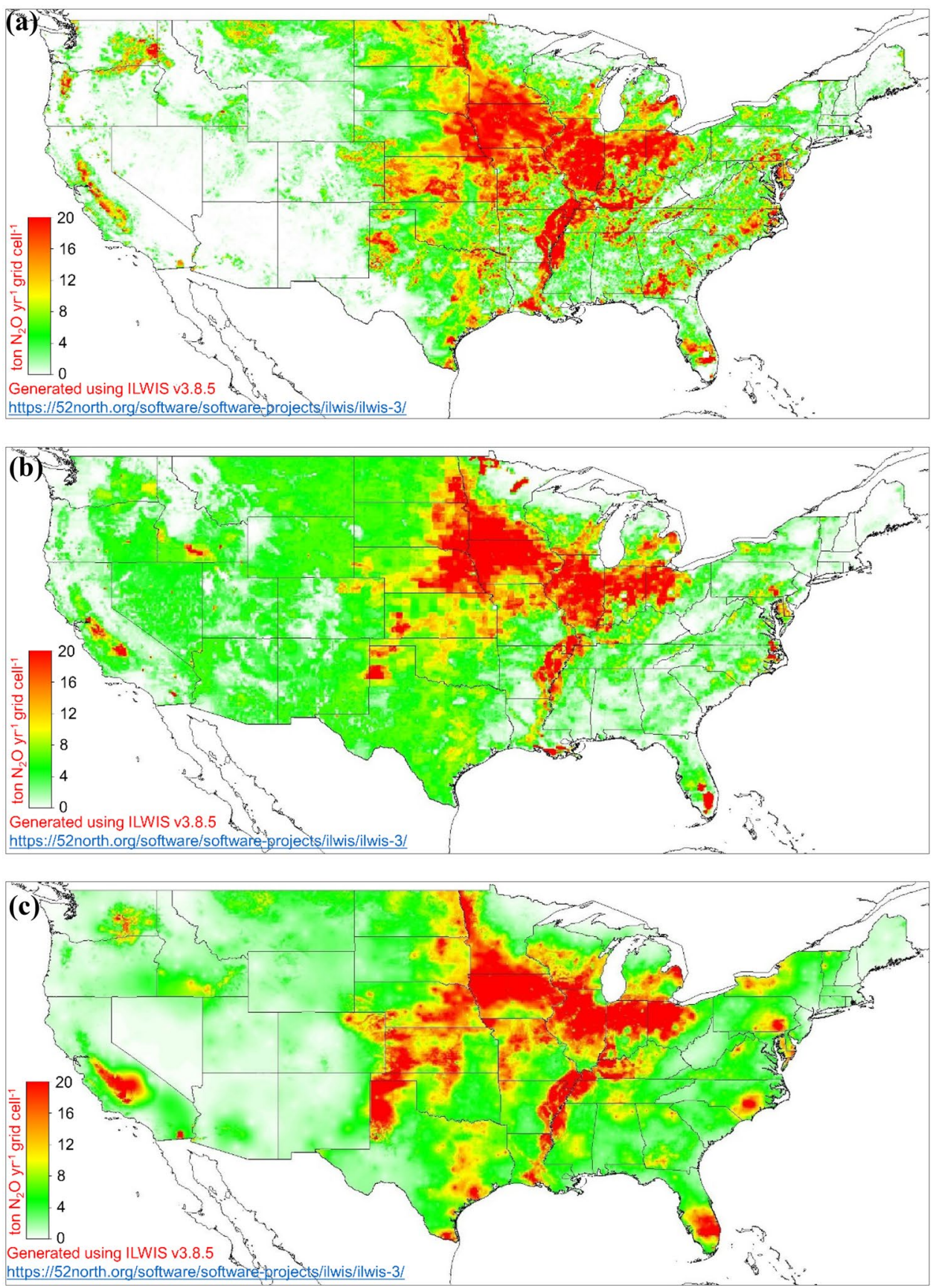

and China) to strengthen our model development. Unlike all previous $\mathrm{N}_{2} \mathrm{O}$ emission studies, our approach relies on global emission measurements rather than emission factors and activity data.

Table 5 summarizes the data comparison between $\mathrm{N}_{2} \mathrm{O}_{-}$ STAT, EDGAR, EPA/USGS, and FAOSTAT for $\mathrm{N}_{2} \mathrm{O}$ emission from agricultural soils for the USA, India, China, and globally. The FAOSTAT, EDGAR, and EPA estimates are slightly different, although consistent given the large uncertainties in the IPCC default methodologies [9]. Tubiello et al. [9] compared $\mathrm{N}_{2} \mathrm{O}$ emission from four databases. The results show that the EPA 2006 and EPA 2011 provided the highest values, while FAOSTAT gave the lowest, consistent with our study.

In developing $\mathrm{N}_{2} \mathrm{O}_{-}$STAT, we collected data for published $\mathrm{N}_{2} \mathrm{O}$ emissions that correspond to the use of fertilizer and manure on particular soils (Supplementary Table 1S). $\mathrm{N}_{2} \mathrm{O}$ _STAT, however, does not include ancillary emissions from leaching and surface runoff, as such information is not often available. As a result, our estimate is only driven by the direct $\mathrm{N}_{2} \mathrm{O}$ emissions from agricultural soils. This may represent a fundamental difference when 

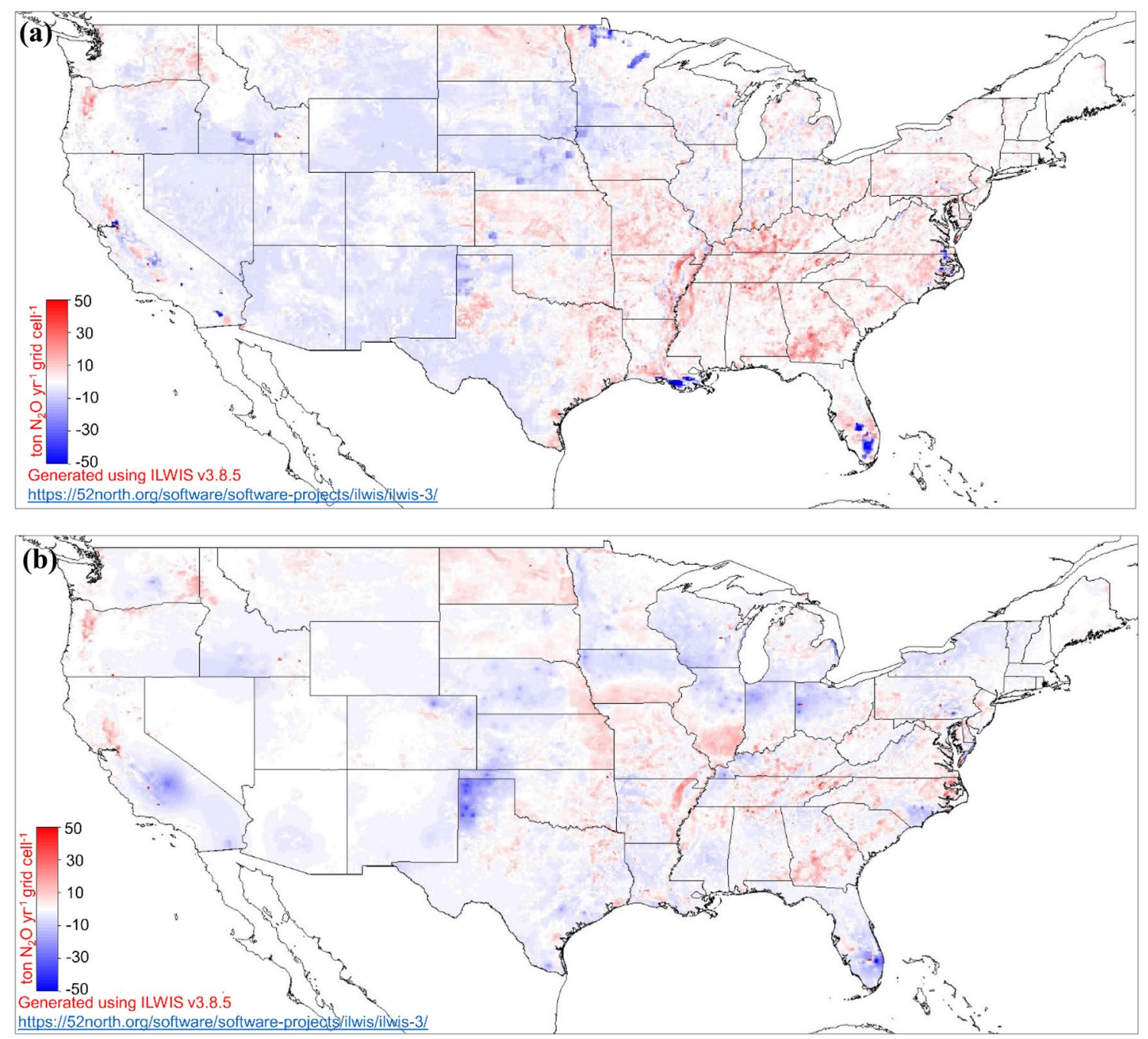

Fig. 5 Absolute difference of $\mathrm{N}_{2} \mathrm{O}$ emissions over CONUS between $\mathbf{a} \mathrm{N}_{2} \mathrm{O}$ _STAT and EDGAR, $\mathbf{b}$ between $\mathrm{N}_{2} \mathrm{O}$ _STAT and EPA/USGS (in ton $\mathrm{N}_{2} \mathrm{O}$ $\mathrm{yr}^{-1}$ grid cell $^{-1}$ ). The maps are generated using ILWIS v3.8.5 (https://52north.org/software/software-projects/ilwis/ilwis-3/)

comparing the results across different data sets. EDGAR and FAOSTAT incorporate both direct and indirect $\mathrm{N}_{2} \mathrm{O}$ emissions in estimating the global emissions. Additionally, the agricultural sources from which the emissions are tabulated for our model are different from other data sets. For example, EDGAR includes rice cultivation and crop residue in its estimate [28]. Another key difference between $\mathrm{N}_{2} \mathrm{O}_{\text {STTAT }}$ and other models lies in the methodology of collecting the model inputs. The $\mathrm{N}_{2} \mathrm{O} \_$STAT model uses the measured $\mathrm{N}_{2} \mathrm{O}$ emissions reported from field experiments, whereas the other approaches derive their emissions by using intermediate data sets (e.g. fertilizer production, livestock counts) and apply emission factors to the corresponding data sets. The $\mathrm{N}_{2} \mathrm{O} \_$STAT model only considers physicochemical variables of the emissions, excluding the soil management practices that might contribute to the emissions. In addition, the methods used to measure
$\mathrm{N}_{2} \mathrm{O}$ emissions in the field were different from one study to another; these differences are not taken into consideration in developing $\mathrm{N}_{2} \mathrm{O} \_$STAT.

The region-based analysis (USA, India, and China) indicates that our model gives lower estimates than other modelling efforts. The global $\mathrm{N}_{2} \mathrm{O}$ agricultural soil emission from $\mathrm{N}_{2} \mathrm{O}_{-}$STAT estimate is $9-20 \%$ lower than EDGAR and FAOSTAT. The major differences, as observed in Fig. 3c, are most prominent in India and China. In India, negative differences are depicted in Fig. $6 \mathrm{c}$ in the northern and central regions, while the positives are mainly to the west and south of the subcontinent. However, the finely resolved agricultural emissions of $\mathrm{N}_{2} \mathrm{O}$ in India [23], as well as from EDGAR and FAOSTAT, agree well with $\mathrm{N}_{2} \mathrm{O} \_$STAT $(<20 \%$ differences). It is to be noted that the estimate from Aneja et al. [23] was calculated for 2003. Despite this difference, there are similarities between these data sets with respect 

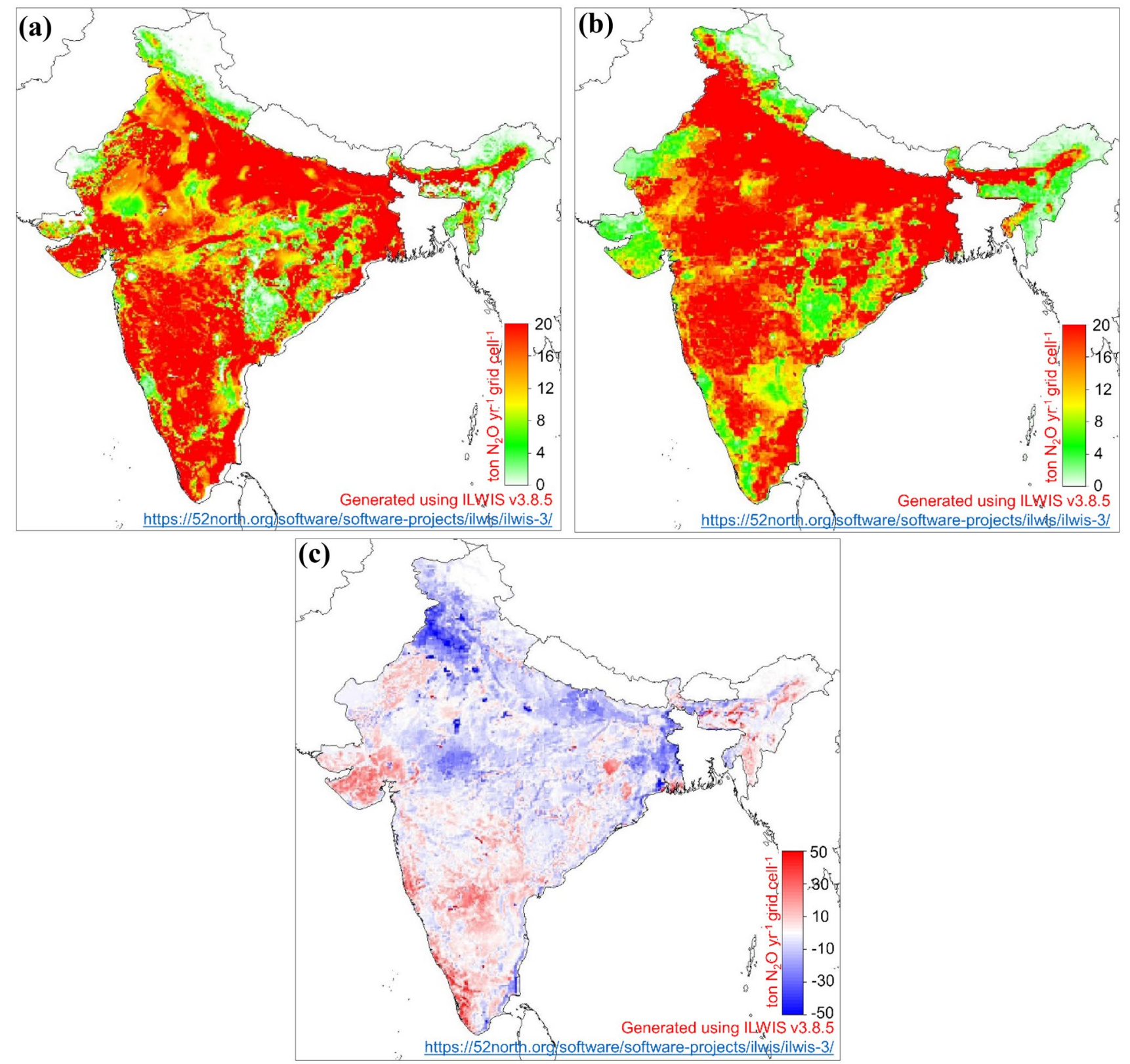

Fig. 6 Comparison between the results from a $\mathrm{N}_{2} \mathrm{O} \_\mathrm{STAT}$, $\mathbf{b}$ EDGAR, and $\mathbf{c}$ the absolute difference between $\mathrm{N}_{2} \mathrm{O} \_\mathrm{STAT}$ and EDGAR (in ton $\mathrm{N}_{2} \mathrm{O} \mathrm{yr}^{-1}$ grid cell $^{-1}$ ). The maps are generated using ILWIS v3.8.5 (https://52north.org/software/software-projects/ilwis/ilwis-3/)

to the areas from which high emissions are estimated. Such similarities are not observed when we compared our model estimate with EDGAR.

Our approach is subject to uncertainty. In particular, our statistical analysis was restricted to parameters which were available in the measurement literature and in global databases. Thus, the analysis did not include parameters such as soil composition and porosity, which could also influence $\mathrm{N}_{2} \mathrm{O}$ emissions. We also do not take into account short-term changes in moisture and temperature which may result in enhanced $\mathrm{N}_{2} \mathrm{O}$ emissions. Further, data were not available to systematically incorporate differences in agricultural practices, such as the cultivation of more than one crop per year, or the use of multiple fertilizer applications in a year. This may account for some of the difference between our estimates and other estimates for China, where two crops are grown per year in many places.

Nevertheless, previous $\mathrm{N}_{2} \mathrm{O}$ emissions inventory approaches are also subject to large uncertainties. Our literature survey identified $\mathrm{N}_{2} \mathrm{O}$ emission factors from less than 0.1 to almost $10 \mathrm{~kg} \mathrm{~N}_{2} \mathrm{O}-\mathrm{N} \mathrm{kg}^{-1} \mathrm{~N}$ applied [29, 30]. This demonstrates the difficulty of using an emission 
Table 5 Summary of $\mathrm{N}_{2} \mathrm{O}$ emission from different inventories

\begin{tabular}{lllll}
\hline Emission inventory & \multicolumn{4}{l}{$\mathrm{N}_{2} \mathrm{O}\left(\mathrm{Tg} \mathrm{N} \mathrm{yr}^{-1}\right)$} \\
\cline { 2 - 5 } & Global & US & India & China \\
\hline $\mathrm{N}_{2} \mathrm{O}$ _STAT & 3.75 & 0.400 & 0.412 & 0.300 \\
EDGAR & 4.49 & 0.432 & 0.468 & 0.832 \\
FAOSTAT & 4.07 & 0.350 & 0.440 & 0.686 \\
Bouwman et al. [32] & 2.80 & - & - & - \\
EPA/USGS & - & 0.457 & - & - \\
EPA Report & - & 0.529 & - & - \\
Aneja et al. [23] & - & - & 0.344 & - \\
Garg et al. [24] & - & - & 0.181 & - \\
Sharma et al. [25] & - & - & 0.226 & - \\
Gao et al. [26] & - & - & - & 0.294 \\
Zhou et al. [27] & - & - & - & 0.414 \\
\hline
\end{tabular}

factor approach to compute $\mathrm{N}_{2} \mathrm{O}$ emissions. In fact, diagnostic tests for our model indicated that $\mathrm{N}_{2} \mathrm{O}$ emissions are a nonlinear function of $\mathrm{N}$ input [22]. $\mathrm{N}_{2} \mathrm{O} \_$STAT can be used to estimate a median value for the $\mathrm{N}_{2} \mathrm{O}$ emission factor by calculating the ratio between $\mathrm{N}_{2} \mathrm{O}$ emission and applied $\mathrm{N}$ fertilizer in every grid cell of the map. We calculated the $\mathrm{N}_{2} \mathrm{O}$ emission factor for USA. In our calculation, we distinguished the two sources of $\mathrm{N}_{2} \mathrm{O}$ emissions, i.e. synthetic fertilizer and organic fertilizer, and determined emission factors for each of these sources. Our results suggest that for the USA, the median values for the emission factor for synthetic fertilizer and organic fertilizer are $1.03 \%$ and $1.52 \%$, respectively, based on the $\mathrm{N}$ input from the fertilizer. The emission factor for synthetic fertilizer is comparable to those from Stehfest and Bouwman [12] (0.9\%) and De Klein et al. [31] (1.0\%).

\section{Conclusion}

$\mathrm{N}_{2} \mathrm{O}_{\text {STAT }}$ is a statistical model developed for characterizing atmospheric $\mathrm{N}_{2} \mathrm{O}$ emissions from agricultural soils. We obtained $\mathrm{N}_{2} \mathrm{O}$ emissions and physicochemical variables (i.e. air temperature, soil temperature, soil moisture, soil $\mathrm{pH}$, and $\mathrm{N}$ input to the soil) from published journal articles since 2000. In comparison with other data sets, the model generates a lower global $\mathrm{N}_{2} \mathrm{O}$ estimate by 9-20\% ( $\mathrm{N}_{2} \mathrm{O}$ _STAT: $3.75 \mathrm{Tg} \mathrm{N} \mathrm{yr}^{-1}$; EDGAR: $4.49 \mathrm{Tg} \mathrm{N} \mathrm{yr}^{-1}$; FAO: $4.07 \mathrm{Tg} \mathrm{N} \mathrm{yr}^{-1}$ ), but is 25\% higher when compared to Bouwman et al. [32] (2.80 $\left.\mathrm{Tg} \mathrm{N} \mathrm{yr}^{-1}\right)$. A region-based analysis (USA, India, and China) using the $\mathrm{N}_{2} \mathrm{O}$ _STAT model produces an estimate for the USA that ranges from -13 to $+32 \%$ in comparison with other published data sets. Meanwhile, the $\mathrm{N}_{2} \mathrm{O}$ SSTAT model estimate for India shows $\mathrm{N}_{2} \mathrm{O}$ emissions between -56 and $+14 \%$ when compared to other data sets. A much lower estimate is seen for China, where the model estimates for $\mathrm{N}_{2} \mathrm{O}$ emissions are $38-177 \%$ lower than other data sets.

The $\mathrm{N}_{2} \mathrm{O}_{-} \mathrm{STAT}$ uses measured values for $\mathrm{N}_{2} \mathrm{O}$ emissions including $\mathrm{N}$ content in the fertilizer to develop the model. The correlations between $\mathrm{N}_{2} \mathrm{O}$ emissions and most physicochemical variables are at a high significance level $(90 \%)$, suggesting that these variables are likely affecting the emissions despite excluding other variables. Moreover, the $\mathrm{N}_{2} \mathrm{O} \_\mathrm{STAT}$ model provides an opportunity to predict future $\mathrm{N}_{2} \mathrm{O}$ emissions in a changing world. This statistical model provides an innovative and relatively simple way to estimate global $\mathrm{N}_{2} \mathrm{O}$ emission from agricultural soils.

The underestimation of $\mathrm{N}_{2} \mathrm{O}$ emissions in comparison with other data sets and the fact that $\mathrm{N}_{2} \mathrm{O}_{-}$STAT may be still missing some key $\mathrm{N}$ inputs to its variables should be taken into account in future work. Parameterization of soil biological activity would more fully represent the processes governing the $\mathrm{N}_{2} \mathrm{O}$ emissions.

Acknowledgments Support for this work was provided by U.S. GFDLNOAA project NOAA CPO AC4. We thank Dr. Larry Horowitz and Dr. Fabien Paulot for their ongoing discussions on the project. We also thank Dr. Francesco Tubiello, UN Food and Agriculture Organization, for discussions of our results.

Author contributions The five co-authors contributed equally to the work; however, VPA and WHS jointly supervised the work. AN prepared the global emission maps. All authors reviewed the manuscript. QL and AN performed the statistical analysis related to the modelling framework.

\section{Compliance with ethical standards}

Conflict of interest The authors declare no competing interests.

\section{References}

1. Myhre G, Shindell D, Bréon F-M, Collins W, Fuglestvedt J, Huang J, Koch D, Lamarque J-F, Lee D, Mendoza B, Nakajima T, Robock A, Stephens G, Takemura T, Zhang H (2013) Anthropogenic and natural radiative forcing. In: Stocker TF, Qin D, G.-K.Plattner, Tignor M, Allen SK, Doschung J, Nauels A, Xia Y, Bex V, Midgley PM (eds) Climate change 2013: the physical science basis. Contribution of working group I to the fifth assessment report of the intergovernmental panel on climate change. Cambridge University Press, Cambridge, pp 659-740

2. Ravishankara AR, Daniel JS, Portmann RW (2009) Nitrous oxide $\left(\mathrm{N}_{2} \mathrm{O}\right)$ : the dominant ozone-depleting substance emitted in the 21 st century. Science 326:123-125. https://doi.org/10.1126/ science. 1176985

3. Forster $P$, Ramaswamy $V$, Artaxo $P$, Berntsen $T$, Betts $R$, Fahey DW, Haywood J, Lean J, Lowe DC, Myhre G (2007) Changes in atmospheric constituents and in radiative forcing. In: Solomon S, Qin D, Manning M, Chen Z, Marquis M, Averyt KB, Tignor M, Miller HL (eds) Climate change 2007. The physical science basis. Cambridge University Press, Cambridge

4. Flückiger J, Monnin E, Stauffer B, Schwander J, Stocker TF, Chappellaz J, Raynaud D, Barnola J-M (2002) High-resolution Holocene 
$\mathrm{N}_{2} \mathrm{O}$ ice core record and its relationship with $\mathrm{CH}_{4}$ and $\mathrm{CO}_{2}$. Global Biogeochem Cycles 16:1-8. https://doi.org/10.1029/2001gb0014 17

5. Ciais P, Sabine C, Bala G, Bopp L, Brovkin V, Canadell J, Chhabra A DeFries R, Galloway J, Heimann M (2014) Carbon and other biogeochemical cycles. In: Stocker TF, Qin D, Plattner G-K, Tignor M, Allen SK, Boschung J, Nauels A, Xia Y, Bex V, Midgley PM (eds) Climate change 2013: the physical science basis. Contribution of working group I to the fifth assessment report of the intergovernmental panel on climate change. Cambridge University Press, pp 465-570

6. Schlesinger WH, Bernhardt ES (2013) Biogeochemistry: an analysis of global change, 3rd edn. Academic Press, New York

7. IPCC (2006) Agriculture, forestry, and other land uses. In: Eggleston HS, Buendia L, Miwa K, Ngara T, Tanabe K (eds) 2006 IPCC guidelines for national greenhouse gas inventories. Volume 4: Agriculture. IGES, Hayama, Japan, pp 1.1-1.21

8. Smith $\mathrm{P}$, Bustamante $\mathrm{M}$, Ahammad $\mathrm{H}$, Clark $\mathrm{H}$, Dong $\mathrm{H}$, Elsiddig EA, Haberl H, Harper R, House J, Jafari M, Masera O, Mbow C, Ravindranath NH, Rice CW, Abad CR, Romanovskaya A, Sperling F, Tubiello F (2014) Agriculture, Forestry, and Other Land Use (AFOLU). In: Edenhofer O, Pichs-Madruga R, Sokona Y, Farahani E, Kadner S, Seyboth K, Adler A, Baum I, Brunner S, Eickemeier P, Kriemann B, Savolainen J, Schlömer S, Stechow C von, Zwickel T, Minx JC (eds) Climate change 2014: mitigation of climate change. Contribution of working group III to the fifth assessment report of the intergovernmental panel on climate change. Cambridge University Press, Cambridge

9. Tubiello FN, Salvatore M, Rossi S, Ferrara AF, Fitton N, Smith $P$ (2013) The FAOSTAT database of greenhouse gas emissions from agriculture. Environ Res Lett 8:15009. https://doi. org/10.1088/1748-9326/8/1/015009

10. Butterbach-Bahl K, Baggs EM, Dannenmann M, Kiese R, Zechmeister-Boltenstern S (2013) Nitrous oxide emissions from soils: how well do we understand the processes and their controls? Philos Trans R Soc Lond B Biol Sci 368:20130122

11. Granli T, Bockman OC (1994) Nitrous oxide from agriculture. Nor J Agric Sci Norw 12:1-128

12. Stehfest $\mathrm{E}$, Bouwman $\mathrm{L}$ (2006) $\mathrm{N}_{2} \mathrm{O}$ and $\mathrm{NO}$ emission from agricultural fields and soils under natural vegetation: summarizing available measurement data and modeling of global annual emissions. Nutr Cycl Agroecosyst 74:207-228. https://doi.org/10.1007/s1070 5-006-9000-7

13. Rezaei Rashti M, Wang W, Moody P, Chen C, Ghadiri H (2015) Fertiliser-induced nitrous oxide emissions from vegetable production in the world and the regulating factors: a review. Atmos Environ 112:225-233. https://doi.org/10.1016/j.atmosenv.2015.04.036

14. Wang Y, Guo J, Vogt RD, Mulder J, Wang J, Zhang X (2017) Soil pH as the chief modifier for regional nitrous oxide emissions: new evidence and implications for global estimates and mitigation. Glob Change Biol 24:e617-e626. https://doi.org/10.1111/gcb.13966

15. Oertel C, Matschullat J, Zurba K, Zimmermann F, Erasmi S (2016) Greenhouse gas emissions from soils: a review. Chem Erde 76:327352. https://doi.org/10.1016/j.chemer.2016.04.002

16. Yu T, Zhuang Q (2019) Quantifying global $\mathrm{N}_{2} \mathrm{O}$ emissions from natural ecosystem soils using trait-based biogeochemistry models. Biogeosciences 16:207-222. https://doi.org/10.5194/ bg-16-207-2019

17. Janssens-Maenhout $G$, Crippa M, Guizzardi D, Muntean M, Schaaf E, Dentener F, Bergamaschi P, Pagliari V, Olivier JGJ, Peters JAHW, van Aardenne JA, Monni S, Doering U, Petrescu AMR (2017) EDGAR v432 global atlas of the three major greenhouse gas emissions for the period 1970-2012. Earth Syst Sci Data Discuss. https ://doi.org/10.5194/essd-2017-79

18. EPA (2018) Inventory of U.S. greenhouse gas emissions and sinks: 1990-2016
19. Gronberg JM, Spahr NE (2012) County-level estimates of nitrogen and phosphorus from commercial fertilizer for the conterminous United States, 1987-2006. US Department of the Interior, US Geological Survey, Reston, VA

20. Gronberg JM, Arnold TL (2017) County-level estimates of nitrogen and phosphorus from animal manure for the conterminous United States, 2007 and 2012. Reston, VA

21. Kim D-G, Giltrap D, Hernandez-Ramirez G (2013) Background nitrous oxide emissions in agricultural and natural lands: a metaanalysis. Plant Soil 373:17-30. https://doi.org/10.1007/s1110 4-013-1762-5

22. Shcherbak I, Millar N, Robertson GP (2014) Global metaanalysis of the nonlinear response of soil nitrous oxide $\left(\mathrm{N}_{2} \mathrm{O}\right)$ emissions to fertilizer nitrogen. Proc Natl Acad Sci 111:9199-9204

23. Aneja VP, Schlesinger WH, Erisman JW, Behera SN, Sharma M, Battye W (2012) Reactive nitrogen emissions from crop and livestock farming in India. Atmos Environ 47:92-103. https://doi. org/10.1016/j.atmosenv.2011.11.026

24. Garg A, Shukla PR, Kapshe M (2006) The sectoral trends of multigas emissions inventory of India. Atmos Environ 40:4608-4620. https ://doi.org/10.1016/j.atmosenv.2006.03.045

25. Sharma SK, Choudhury A, Sarkar P, Biswas S, Singh A, Dadhich PK, Singh AK, Majumdar S, Bhatia A, Mohini M, Kumar R, Jha CS, Murthy MSR, Ravindranath NH, Bhattacharya JK, Karthik M, Bhattacharya S, Chauhan R (2011) Greenhouse gas inventory estimates for India. Curr Sci 101:1-11. https://doi.org/10.5465/amle.2013.0201

26. Gao B, Ju XT, Zhang Q, Christie P, Zhang FS (2011) New estimates of direct N 20 emissions from Chinese croplands from 1980 to 2007 using localized emission factors. Biogeosciences 8:3011-3024. https://doi.org/10.5194/bg-8-3011-2011

27. Zhou F, Shang Z, Ciais P, Tao S, Piao S, Raymond P, He C, Li B, Wang R, Wang X, Peng S, Zeng Z, Chen H, Ying N, Hou X, Xu P (2014) A new high-resolution $\mathrm{N}_{2} \mathrm{O}$ emission inventory for China in 2008. Environ Sci Technol 48:8538-8547. https://doi.org/10.1021/es501 8027

28. IPCC (1996) Revised 1996 IPCC guideline for national greenhouse gas inventories, Common reporting framework: agriculture

29. Majumdar D, Kumar S, Pathak H, Jain MC, Kumar U (2000) Reducing nitrous oxide emission from an irrigated rice field of North India with nitrification inhibitors. Agric Ecosyst Environ 81:163169. https://doi.org/10.1016/S0167-8809(00)00156-0

30. Shimizu M, Hatano R, Arita T, Kouda Y, Mori A, Matsuura S, Niimi M, Jin T, Desyatkin AR, Kawamura O, Hojito M, Miyata A (2013) The effect of fertilizer and manure application on $\mathrm{CH}_{4}$ and $\mathrm{N}_{2} \mathrm{O}$ emissions from managed grasslands in Japan. Soil Sci Plant Nutr 59:69-86. https://doi.org/10.1080/09644016.2014.943010

31. De Klein C, Novoa RSA, Ogle S, Smith KA, Rochette P, Wirth TC, McConkey BG, Mosier A, Rypdal K (2006) $\mathrm{N}_{2} \mathrm{O}$ emissions from managed soils, and $\mathrm{CO}_{2}$ emissions from lime and urea application (Chapter 11). Geneva

32. Bouwman AF, Boumans LJM, Batjes NH (2002) Modeling global annual $\mathrm{N}_{2} \mathrm{O}$ and $\mathrm{NO}$ emissions from fertilized fields. Global Biogeochem Cycles 16:1-9. https://doi.org/10.1029/2001gb001812

33. NOAA (2019) Halocarbon and other atmospheric trace gases: nitrous oxide $\left(\mathrm{N}_{2} \mathrm{O}\right)$ - dataset. https://www.esrl.noaa.gov/gmd/ hats/combined/N2O.html. Accessed 10 July 2019

34. Firestone MKK, Davidson EAA (1989) Microbiological basis of NO and $\mathrm{N}_{2} \mathrm{O}$ production and consumption in soil. Exch Trace Gases Between Terr Ecosyst Atmos 47:7-21. https://doi.org/10.1017/ CBO9781107415324.004

Publisher's Note Springer Nature remains neutral with regard to jurisdictional claims in published maps and institutional affiliations. 